\title{
filftortlde Beitldertift
}

herauggegeben bon

\section{Secitridh von Sybel,}

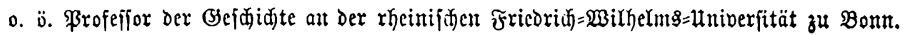

\author{
Zefhuter Banto.
}

\author{
Mändxen, 1863.

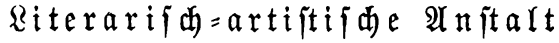

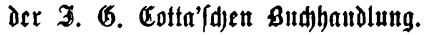

Reprinted with the permission of R. Oldenbourg Verlag JOHNSON REPRINT CORPORATION JOHNSON REPRINT COMPANY LTD. 111 Fifth Avenue, New York, N.Y. 10003 Berkeley Square House, I.ondon, W. 1 
First reprinting, I 968, Johnson Reprint Corporation Printed in the United States of America 